\title{
Prevalence of non-organ-specific autoantibodies in a rural community from northeastern Brazil: a population-based study
}

\author{
Liliane M. Cunha a , Paulo L. Bittencourt ${ }^{\mathrm{a}, \mathrm{b}, *}$, Clarice P. Abrantes-Lemos ${ }^{\mathrm{c}}$, Agnaluce Moreira ${ }^{\mathrm{d}}$, \\ Delvone Almeida $^{\mathrm{e}}$, Raymundo Parana ${ }^{\mathrm{e}}$, Zilton Andrade ${ }^{\mathrm{a}}$ \\ a Gonçalo Moniz Research Center-Fiocruz, Bahia, Brazil \\ b Portuguese Hospital of Salvador, Bahia, Brazil \\ ${ }^{\mathrm{c}}$ University of São Paulo School of Medicine, São Paulo, Brazil \\ ${ }^{\mathrm{d}}$ LPC Laboratory, Salvador, Bahia, Brazil \\ e Federal University of Bahia, Bahia, Brazil
}

\section{A R T I C L E I N F O}

\section{Article history:}

Received 9 May 2011

Accepted 3 October 2011

Available online 8 October 2011

\section{Keywords:}

Autoantibodies

Rural population

Autoimmunity

Autoimmune diseases

Liver diseases

\begin{abstract}
A B S T R A C T
Non-organ-specific autoantibodies (NOSA) are well-recognized diagnostic markers of autoimmune hepatitis $(\mathrm{AIH})$ and primary biliary cirrhosis (PBC), but can also be observed in patients with viral hepatitis as well as in healthy subjects. The aim of this study was to evaluate the prevalence of NOSA in subjects living in a rural community in Brazil and to correlate their occurrence with the presence of liver disease. Seven hundred twenty-five apparently healthy subjects were randomly selected for assessment of antinuclear (ANA), anti-smooth muscle (SMA), antimitochondrial (AMA), anti-liver/kidney microsome type 1, and anti-liver cytosol type 1 antibodies. Subjects with those NOSA were evaluated for the presence of AIH, PBC, and viral hepatitis. Reactivities for all NOSA, SMA, ANA, and AMA were detected, respectively, in $14,10,4$, and $0.1 \%$ of subjects, with a mean titer of 1:40. NOSA-positive subjects were significantly older and more frequently females. No correlation was observed between the occurrence of NOSA and PBC, AIH, or viral hepatitis. The prevalence of NOSA in Brazilians was 14\%. They were usually low titer. NOSA were more frequently observed in females and older subjects and their presence was not correlated with the presence of AIH, PBC, or viral hepatitis.
\end{abstract}

(C) 2012 American Society for Histocompatibility and Immunogenetics. Published by Elsevier Inc. All rights reserved.

\section{Introduction}

Non-organ-specifc autoantibodies (NOSA) may be observed in healthy subjects as part of the circulating repertoire of naturally occurring autoantibodies (Nabs). By contrast, several NOSA are also recognized as diagnostic markers of several autoimmune diseases [1]. In this regard, antinuclear (ANA), anti-smooth muscle (SMA), antimitochondrial (AMA), antisoluble liver antigen/liver-pancreas, anti-liver/kidney microsome type 1 (anti-LKM1), and anti-liver cytosol type 1 (anti-LC1) antibodies are employed, usually when titers are high, for the diagnosis of autoimmune liver diseases such as autoimmune hepatitis (AIH) [2] and primary biliary cirrhosis (PBC) [3]. However, they are also usually reported, particularly ANA and SMA, in 1-43\% of apparently healthy subjects [4-8], in 14$66 \%$ [9] of patients with chronic hepatitis C, and in up to $90 \%$ of patients with autoimmune rheumatic diseases [10].

In contrast to disease-associated NOSA, Nabs were demonstrated to be germline-type antibodies, usually but not exclusively of immunoglobulin (Ig)-M isotype, and displaying multireactivity and low affinity for antigens [11-13]. They tend to cluster in fe-

\footnotetext{
* Corresponding author.

E-mail address: plbbr@uol.com.br (P. L. Bittencourt).
}

males [7,14] and in the elderly [4,5,14-16]. By contrast, the occurrence of NOSA may be associated with an enhanced predisposition or even the presence of occult liver disease, as previously reported for AMA as well as for other NOSA, such as SMA, ANA, or anti-LKM1, respectively, for $\mathrm{PBC}[17,18]$, and for hepatitis $C$ [9,19-26]. However, with the exception of AMA, data concerning the significance of those aforementioned NOSA as surrogate markers of autoimmune or viral diseases of the liver are lacking.

The purpose of the present study was to investigate the prevalence of NOSA in apparently healthy subjects from a rural community in the northeastern region of Brazil, to analyze their occurrence according to age and gender and the presence autoimmune liver diseases, as well as with evidence of past or present infection with hepatitis $\mathrm{A}(\mathrm{HAV}), \mathrm{B}(\mathrm{HBV})$, and C (HCV) virus.

\section{Subjects and methods}

\subsection{Study population}

This study was conducted in the district of Cavunge in Ipacaeta County in the semiarid region of Bahia, Brazil. The district had a population in 1999 of 2,049 subjects living in an area of $63.5 \mathrm{~km}^{2}$ composed of 1 small village and several rural settlements scattered 
Table 1

Demographic features of subjects from Cavunge County ${ }^{\mathrm{a}}$

\begin{tabular}{lc}
\hline$N$ & 725 \\
\hline$\%$ of the estimated population $(n=2,049)$ & $35 \%$ \\
Female sex & $369(51 \%)$ \\
Age (years) & $23(0.2-91)$ \\
Age less than 16 years & $39 \%$ \\
Place of residence & \\
$\quad$ Urban area & $27 \%$ \\
Rural area & $73 \%$ \\
\hline
\end{tabular}

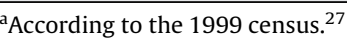

in distinct farms. The demographic features and socioeconomic status of this population were previously described [27,28]. Briefly, its inhabitants were of highly admixed origin with differing percentages of Caucasoid, Negroid, and Amerindian ancestries. Most of the population lived in the rural settlements and were of poor socioeconomic status, with their main income derived from subsistence farming, relying on growing corn, beans, and cassava. Nearly half were illiterate.

The present study is part of a large project sponsored by the Brazilian National Health Foundation to perform a sentinel surveillance of HAV, HBV, and HCV infection in northeastern Brazil. According to the methodology employed, data collection was carried out in the Cavunge district at 2 different time periods.

In the first round of the project, carried out between 1999 and $2000,1,800$ subjects from Cavunge were enrolled to assess the prevalence of past or current infection with HAV, HBV, and HCV [28].

The second part of the project was carried out after 2004 to provide data collection for the prevalence of HAV, HBV, and HCV infection at least 5 years apart. During this time period, participants of this sentinel surveillance study were randomly invited by local agents from the Brazilian Family Health Program to be enrolled in the present investigation concerning the prevalence and significance of NOSA in the Cavunge District.

All subjects or their legal guardians who agreed to take part in the study had given their informed consent. Participants were required to state residence in the Cavunge District for more than 6 months.

Subjects who were unable to understand the principles of the study, such as those with chronic degenerative cerebrovascular disorders or psychiatric illness, were excluded from the current investigation, as well as all subjects less than 18 years of age without formal consent of their parents or legal guardians. Subjects who either required hospitalization or needed medical care in the previous 6 months were also excluded. Subjects less than 16 years of age were arbitrarily defined as children.

The study was approved by the Ethics Committee in Research of the Prof. Edgard Santos University Hospital and by the National Ethics Research Council.

Seven hundred twenty-five subjects were accepted to participate and underwent an interview to gather demographic data such as age, gender, and local address. Subsequently, blood samples were collected and processed into 1 to 4 aliquots of $1 \mathrm{~mL}$ of plasma, subsequently frozen, and stored at $-80^{\circ} \mathrm{C}$. Only a $1-\mathrm{mL}$ aliquot was separated for NOSA determination.

\subsection{Autoantibodies}

All subjects were screened for SMA, ANA, AMA, anti-LKM1, and anti-LC1 antibodies by indirect immunofluorescence (IIF) at a screening dilution of 1:40 on rat liver, kidney, and stomach tissue sections according to international criteria [29]. SMA reactivity was further characterized as vessel (V), glomeruli $(G)$, and tubule (T) patterns according to Bottazzo et al. [30]. All $\mathrm{SMA}^{+}$subjects had their sera subsequently tested for antiactin (microfilament) reactivity by IIF at a screening dilution of 1:20 using the heat serum inactivation technique [31]. All sera were also tested for ANA on HEp-2 cells using a commercially available kit (code 44509, Biosystems, Barcelona, Spain). Reactivities for anti-LKM1 and/or anti-LC1 as well as for AMA, whenever present, were further confirmed by immunoblotting, respectively, using rat liver microsomal fractions [32,33], human liver cytosol [34], and submitochondrial fractions of beef heart as the source of antigens [35-37], as previously described.

\subsection{Viral markers}

Serologic markers of past or present hepatitis A, B, and C infection, including anti-HAV antibody (anti-HAV) IgG, hepatitis B surface antigen (HBsAg), anti-hepatitis B core antigen antibody (antiHBC IgG), anti-hepatitis B surface antigen antibody (anti-HBs), and anti-HCV antibody (anti-HCV; ELISA III, Roche, Basel, Switzerland) were performed in the first round of the project. All anti-HCV ${ }^{+}$ samples were subsequently examined for HCV-RNA quantification and genotyping.

\subsection{Clinical follow-up}

Subjects with reactivity to SMA, ANA, or anti-LKM1 at titers equal to or higher than 1:80 and to AMA at titers equal or higher than 1:40 were submitted to subsequent clinical and laboratory evaluation to assess the presence of $\mathrm{AIH}, \mathrm{PBC}$, and primary sclerosing cholangitis, as well as other viral and metabolic liver disorders. The titers were arbitrarily chosen as clinically relevant based on published guidelines for the diagnosis of AIH and PBC [2,3]. All patients with evidence of current infection with HBV or HCV were further investigated and treated whenever indicated according to established clinical, laboratory, and histologic criteria.

\subsection{Statistical analysis}

Clinical and laboratory data were compared using the $\chi^{2}$ test with Yates' correction or the Mann-Whitney test when appropriate. A $p$ value $<0.05$ was considered significant. Clinical data are presented in the text and tables as median and range.

\section{Results}

Seven hundred twenty-five subjects (369 females, median age of 23 [0.2-91] years) from the rural community of Cavunge were evaluated. All were apparently healthy. Demographic data concerning those subjects are summarized in Table 1 . Thirty-nine percent were less than 16 years of age and were considered children. Most subjects were living in the rural area of Cavunge County.

One hundred one subjects (14\%) exhibited reactivity for NOSA. Positivity of SMA, ANA, and AMA was observed in 74 (10\%), 32 (4\%), and $1(0.1 \%)$ subject, respectively. Six had concurrent reactivity for SMA and ANA and none of the subjects had either anti-LKM1 or anti-LC1 by IIF. Seventy-two (71\%) subjects had NOSA at titers equal

Table 2

Frequency of non-organ-specific autoantibodies (NOSA) according to titers and immunofluorescence patterns in subjects from Cavunge County

\begin{tabular}{lrrr}
\hline & \multicolumn{3}{l}{ NOSA titers $(\%)$} \\
\cline { 2 - 4 } & $1: 40$ & $1: 80$ & $1: 320$ \\
\hline NOSA $(n=101)$ & $72(71)$ & $28(28)$ & $1(0.9)$ \\
SMA $(n=74)$ & $51(69)$ & $23(31)$ & $0(0)$ \\
V pattern $(n=59)$ & $43(58)$ & $16(22)$ & \\
G pattern $(n=15)$ & $8(11)$ & $7(9)$ & \\
ANA $(n=32)$ & $26(81)$ & $5(16)$ & $1(3)$ \\
Nuclear coarse speckled pattern $(n=27)$ & $26(81)$ & $1(3)$ & \\
Nucleolar homogeneous pattern $(n=2)$ & & $1(3)$ & $1(3)$ \\
Fibrillar cytoplasmatic pattern $(n=2)$ & & $2(6)$ & \\
Nuclear homogeneous pattern $(n=1)$ & & $1(3)$ & \\
AMA $(n=1)$ & & $1(100)$ & \\
\hline
\end{tabular}


Table 3

Comparison of demographic features of subjects from Cavunge County according to the occurrence of NOSA

\begin{tabular}{|c|c|c|c|c|}
\hline & \multicolumn{3}{|c|}{ Subjects with NOSA } & \multirow{2}{*}{$\begin{array}{l}\text { Subjects } \\
\text { without NOSA } \\
\text { Total } \\
(n=624)\end{array}$} \\
\hline & $\begin{array}{l}\text { Total } \\
(n=101)\end{array}$ & $\begin{array}{l}\mathrm{SMA}^{+} \\
(n=74)\end{array}$ & $\begin{array}{l}\mathrm{ANA}^{+} \\
(n=32)\end{array}$ & \\
\hline \multicolumn{5}{|c|}{ Demographic features } \\
\hline Age (years) & $25(0.5-91)^{a}$ & $27(1-91)^{\mathrm{b}}$ & $18(0.5-81)$ & $23(0.2-85)$ \\
\hline Female sex & $72(72)^{c}$ & $53(72)^{d}$ & $23(72)^{\mathrm{e}}$ & $297(48)$ \\
\hline \multicolumn{5}{|c|}{ Place of residence } \\
\hline Urban area & $27 \%$ & $23 \%$ & $31 \%$ & $26 \%$ \\
\hline Rural area & $73 \%$ & $77 \%$ & $69 \%$ & $74 \%$ \\
\hline
\end{tabular}

Numbers in parentheses are percentages. Superscript letters indicate values different from apparently healthy subjects without NOSA at the level of ${ }^{\mathrm{a}} p=0.05 ;{ }^{\mathrm{b}} p=$ NS; ${ }^{c} p=0,00002 ;{ }^{d} p=0,0003$, and ${ }^{\mathrm{e}} p=0.02$

to $1: 40$, whereas $23(31 \%)$ subjects with SMA and 6 (19\%) with ANA had titers equal to or higher than 1:80 (Table 2).

Analysis of IIF patterns of those subjects with SMA revealed that $59(80 \%)$ and 15 (20\%) subjects had SMA-V and -G and none exhibited the SMA-T pattern. Antimicrofilament antibody at a titer of $1: 20$ was observed in only 1 patient with the SMA-G pattern at a titer of 1:80. All but 5(84\%) subjects with ANA exhibited the nuclear coarse speckled pattern. The other IIF patterns encountered were nucleolar homogeneous $(n=2)$, fibrillar cytoplasmic $(n=2)$, and nuclear homogeneous $(n=1)$. All but 1 subject with the nuclear coarse speckled pattern had titers equal to $1: 40$, whereas all subjects with other ANA patterns exhibited titers equal to or higher than 1:80 (Table 2).

The only female subject with reactivity for AMA had titers equal to $1: 80$ by IF, but the search for anti-M2 antibody by immunoblotting yielded negative results.

Analysis of demographic features of those subjects from Cavunge County according to the presence of NOSA revealed that subjects with NOSA (median age of 25 [0.5-91] years vs 23 [0.2-85] years in subjects without NOSA, $p=0.05$ ) were older when compared with their counterparts without NOSA (Table 3 ), but the frequencies of NOSA were similar in children compared with adults ( $13 \%$ in children vs $16 \%$ in adults, $p=N S$ ). In addition, subjects with NOSA, either SMA or ANA, were more frequently females (72\% vs $48 \%$ of subjects without NOSA, $p=0.00002$ ) when compared with their counterparts without NOSA (Table 3 ).

Serologic markers for HAV, HBV, and HCV were available for those 305 subjects who also took part in the first round of the project. Results for the remaining 420 subjects who were subsequently enrolled in this study were still pending at the time of this writing. The prevalence of positivity for all viral markers, IgG anti$\mathrm{HAV}, \mathrm{AgHbs}, \mathrm{IgG}$ anti-HBC, and anti-HCV in those tested subjects was $90,2.4,8.4$, and $0.3 \%$, respectively. No correlation was disclosed between the occurrence of NOSA and serologic evidence of past or ongoing infection with HAV, HBV, or HCV (Table 4).
Twenty-four subjects (17 females, median age of 22 [2-86] years) had NOSA at clinically relevant titers equal to or higher than 1:80 for SMA and ANA or equal to or higher than 1:40 for AMA. All were subsequently evaluated for the presence of liver diseases, including AIH and PBC. None had any clinical evidence of rheumatoid or liver disease. Higher levels of aspartate aminotransferase (1.1 times the upper limit of normal) were disclosed in $1 \mathrm{SMA}^{+}$with a $V$ pattern and a titer greater than 1:80. No other subject, including the $\mathrm{AMA}^{+}$women, had abnormal liver enzymes.

\section{Discussion}

The present study demonstrated a frequency of NOSA of $14 \%$ in apparently healthy subjects, particularly SMA (10\%) and ANA (4\%). The occurrence of NOSA was more common in females and older subjects. Higher frequencies of ANA [8,14,38-43] and SMA [8,1416,38 ] were previously disclosed in apparently healthy subjects in some but not all studies $[4,5,7,19,39,44]$, leading altogether to a great variability in the reported frequency of NOSA in the literature, ranging from 1.5 to $43 \%[4,8]$. This heterogeneity was probably caused by differences in the methodologies used in most of the reports. Several studies have employed blood donors $[5,39,42,44,45]$ as apparently healthy subjects and most investigators have also used nonstandardized IIF techniques recognizing low titers of NOSA, different from those currently recommended by the International Autoimmune Hepatitis Group [29]. In addition, the striking differences observed in socioeconomic status, ethnicity, and demographics of the subjects included in the aforementioned studies may have influenced their results because they do play a role in the expression of Nabs.

Two previous population-based studies [4,7] also revealed a lower prevalence of NOSA in the general population. Njemini et al. [7] reported a frequency of either SMA or ANA of $9 \%$ of the patients in western Africa, whereas Hooper et al. [4] have disclosed a prevalence of 1.5 and $2 \%$ of SMA and ANA, respectively, in Busselton (Australia).

Similar to our findings, enhanced predisposition of NOSA in females was reported in some [7,14], but not all studies [15]. Conversely, older age was also correlated with the occurrence of NOSA in several reports $[4,5,14,15]$.

Analysis of SMA patterns of reactivity revealed SMA-G and -V that are frequently encountered in the general population in all subjects. No subject had the tubular pattern and only 1 had lowtiter antimicrofilament antibody, previously associated with a higher specificity for the diagnosis of AIH [29]. With regard to ANA, most subjects had the low-titer nuclear coarse speckled pattern that was previously demonstrated to be more common in patients with autoimmune rheumatoid disorders compared with controls [46-48], but it must be pointed out that patterns of IIF reactivities of ANA do overlap greatly between patients and apparently healthy controls [42,43,47-49]. These data altogether endorse the relevance of the proper interpretation of NOSA patterns for the diagnosis of autoimmune diseases.

Table 4

Analysis of results of viral markers for past or ongoing infection with hepatitis A, B, and C virus according to the occurrence of NOSA

\begin{tabular}{|c|c|c|c|c|}
\hline \multirow[t]{2}{*}{ Presence of viral markers } & \multicolumn{3}{|l|}{ Subjects with NOSA } & \multirow{2}{*}{$\begin{array}{l}\text { Subjects without NOSA } \\
\text { Total }(n=225)(\%)\end{array}$} \\
\hline & Total $(n=80)(\%)$ & $\operatorname{SMA}(n=59)(\%)$ & ANA $(n=25)(\%)$ & \\
\hline $\begin{array}{l}\text { IgG anti-HAV and/or HBsAg and/or total anti-HBc } \\
\text { and/or anti-HBs and/or anti-HCV }\end{array}$ & 94 & 92 & 96 & 88 \\
\hline IgG anti-HAV & 75 & 75 & 72 & 78 \\
\hline HBsAg & 2.2 & 1.6 & 3.3 & 0.3 \\
\hline Anti-HBc total & 11 & 10 & 6 & 12 \\
\hline $\mathrm{HBsAg}$ and/or anti-HBc total and/or anti-HBs & 18 & 16 & 15 & 19 \\
\hline Anti-HCV & 1 & 2 & 0 & 0 \\
\hline
\end{tabular}

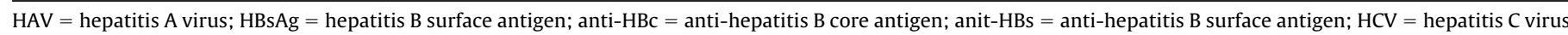


The absence of anti-LKM1 and anti-LC1 in subjects from the present study was not unexpected because those autoantibodies are mostly observed only in patients with AIH and less often in hepatitis C patients [29,50]. By contrast, AMA was observed in only 1 female subject. Its reactivity was not confirmed by immunoblotting. These findings are in accordance with other studies, which have described AMA in less than $1 \%$ of the general population [51]. However, it must be emphasized that AMA, particularly when confirmed by the detection of anti-M2 using either enzyme-linked immunosorbent assay or immunoblotting, is specific for the diagnosis of PBC as well as enhanced predisposition for development of the disease in the long term [17]. Our $\mathrm{AMA}^{+}$subject had no evidence of liver disease and no reactivity for anti-M2 antibody.

The occurrence of NOSA in the present study was not associated with overt autoimmune rheumatoid disease or with the presence of liver disease, including PBC and AIH. Only 1 patient had a slight elevation of aspartate aminotransferase 1.1 times the upper limit of normal that was not correlated with any sign or symptom of liver disease and no laboratory evidence of viral, metabolic, or autoimmune liver disorders. The frequency of NOSA in cohorts of patients with HBV and HCV varies from 2 to $66 \%$ [9,20,21,22,23,26]. However, no association of NOSA with past or present HAV, HBV, or HCV infection was elicited in this investigation, suggesting, on the contrary, that the occurrence of NOSA is not related to undiagnosed or occult HBV or HCV infection or with past history of infection with hepatotropic virus. However, it should be stressed that the lack of association between NOSA and viral infection in the present study could be caused by the very low prevalence of current HBV and HCV infection in the study cohort.

In summary, NOSA, particularly SMA and ANA, can be observed in fewer than $10 \%$ of the apparently healthy population, whereas AMA, anti-LKM1, or anti-LC1 is either rare or absent in subjects without autoimmune liver diseases. In the general population, NOSA are more often encountered in females and in older subjects. They are usually in low titers and exhibit patterns of reactivity without specificity for rheumatoid or liver disorders. Their occurrence is not related to the presence of undiagnosed AIH or PBC and they are not surrogate markers for past or active infection of HAV, $\mathrm{HBV}$, or HCV.

\section{Acknowledgments}

The authors thank the National Research Council (CNPq) of Brazil and the Centro de Pesquisas Goncalo Moniz, Fundação Oswaldo Cruz (FIOCRUZ), for funding and Dr. Maria Alice Sant'Anna Zarife for performing the determination of several viral markers.

\section{References}

[1] Racanelli V, Prete M, Musaraj G, Dammacco F, Perosa F. Autoantibodies to intracellular antigens: generation and pathogenetic role. Autoimmun Rev 2011;10:503-8.

[2] Alvarez F, Berg PA, Bianchi FB, Bianchi L, Burroughs AK, Cancado EL, et al. International Autoimmune Hepatitis Group Report: review of criteria for diagnosis of autoimmune hepatitis. J Hepatol 1999;31:929-38.

[3] Heathcote EJ. Management of primary biliary cirrhosis. The American Association for the Study of Liver Diseases practice guidelines. Hepatology 2000;31: 1005-13.

[4] Hooper B, Whittingham S, Mathews JD, Mackay IR, Curnow DH. Autoimmunity in a rural community. Clin Exp Immunol 1972;12:79-87.

[5] Andersen P. Correlation of smooth-muscle and nuclear antibodies in normal subjects. Clin Exp Immunol 1977;27:74-7.

[6] Smikle MF, James OB. Seroprevalence of autoantibodies in selected and unselected populations in Jamaica. West Indian Med J 1994;43:59-62.

[7] Njemini R, Meyers I, Demanet C, Smitz J, Sosso M, Mets T. The prevalence of autoantibodies in an elderly sub-Saharan African population. Clin Exp Immunol 2002;127:99-106.

[8] Teubner A, Tillmann HL, Schuppan D, Gericke G, Manns MP, Stölzel U. Prevalence of circulating autoantibodies in healthy individuals. Med Klin 2002;97: 645-9.

[9] Clifford BD, Donahue D, Smith L, Cable E, Luttig B, Manns M, et al. High prevalence of serological markers of autoimmunity in patients with chronic hepatitis C. Hepatology 1995;21:613-19.
[10] Mariz HA, Sato EI, Barbosa SH, Rodrigues SH, Dellavance A, Andrade LEC Pattern on the antinuclear antibody-HEp-2 test is a critical parameter for discriminating antinuclear antibody-positive healthy individuals and patients with autoimmune rheumatic diseases. Arthritis Rheum 2011;63:191-200.

[11] Tomer Y, Shoenfeld Y. The significance of natural autoantibodies. Immunol Investig 1988; $17: 389-424$.

[12] Senécal JL, Ichiki S, Girard D, Raymond Y. Autoantibodies to nuclear lamins and to intermediate filament proteins: natural, pathologic or pathogenic? J Rheumatol 1993;20:211-19.

[13] Zelenay S, Moraes Fontes MF, Fesel C, Demengeot J, Coutinho A. Physiopathology of natural auto-antibodies: the case for regulation. J Autoimmun 2007;29: 229-35.

[14] Al-Jabri AA, Al Belushi, MS, Nsanze H. Frequency and levels of autoantibodies in healthy adult Omanis. Ann Saudi Med 2003;23:372-5.

[15] Whitehouse JMA, Holborow EJ. Smooth muscle antibody in malignant disease. Br Med J 1971;4:511-3.

[16] Al Jabri AA, Al Buloshi MS. Anticardiolipin and antinuclear antibodies in the adult healthy Omani individuals. Saudi Med J 2004;25:313-7.

[17] Metcalf JV, Mitchison HC, Palmer JM, Jones DE, Bassendine MF, James OF Natural history of early primary biliary cirrhosis. Lancet 1996;348:1399-402.

[18] Rigopoulou EI, Davies ET, Pares A, Zachou K, Liaskos C, Bogdanos DP, et al. Prevalence and clinical significance of isotype specific antinuclear antibodies in primary biliary cirrhosis. Gut 2005;54:528-32.

[19] Lenzi M, Bellentani S, Saccoccio G, Muratori P, Masutti F, Muratori L, et al Prevalence of non-organ-specific autoantibodies and chronic liver disease in the general population: a nested case-control study of the Dionysos cohort. Gut 1999;45:435-41.

[20] Czaja AJ, Manns MP, Homburger HA. Frequency and significance of antibodies to liver/kidney microsome type 1 in adults with chronic active hepatitis. Gastroenterology 1992;103:1290-5.

[21] Czaja AJ, Carpenter HA, Santrach PJ, Moore SB, Taswell HF, Homburger HA Evidence against hepatitis viruses as important causes of severe autoimmune hepatitis in the United States. J Hepatol 1993;18:342-52.

[22] Fried MW, Draguesku JO, Shindo M, Simpson LH, Banks SM, Hoofnagle JH, et al Clinical and serological differentiation of autoimmune and hepatitis $C$ virusrelated chronic hepatitis. Dig Dis Sci 1993;38:631-6.

[23] Reddy KR, Krawitt EL, Homberg JC, Jeffers LJ, de Medina M, Chastenay B, et al Absence of anti-LKM-1 antibody in hepatitis C viral infection in the United States of America. J Viral Hepat 1995;2:175-9.

[24] Cassani F, Muratori L, Manotti P, Lenzi M, Fusconi M, Ballardini G, et al. Serum autoantibodies and the diagnosis of type- 1 autoimmune hepatitis in Italy: a reappraisal at the light of hepatitis C virus infection. Gut 1993;33:1260-3.

[25] Abuaf N, Lunel F, Giral P, Borotto E, Laperche S, Poupon R, et al. Non-organspecific autoantibodies associated with chronic $C$ virus hepatitis. J Hepatol 1993:18:359-64.

[26] Bortolotti F, Vajro P, Balli F, Giacchino R, Crivellaro C, Barbera C, et al. Nonorgan-specific autoantibodies in children with chronic hepatitis C. J Hepatol 1996;25:614-20.

[27] Tavares-Neto J, Barral A, Queiroz-Andrade M, Oliveira S. Caracterização sóciodemográfica da população do povoado de Cavunge, Bahia. Rev Baiana Saúde Pública 2003;27:60-75

[28] Almeida D, Tavares-Neto J, Vitvitski L, Almeida A, Mello C, Santana D, et al Serological markers of hepatitis A, B and C viruses in rural communities of the semiarid Brazilian Northeast. Braz J Infect Dis 2006;10:317-21.

[29] Vergani D, Alvarez F, Bianchi FB, Cançado ELR, Mackay IR, Manns MP, et al. Liver autoimmune serology: a consensus statement from the committee for autoimmune serology of the International Autoimmune Hepatitis Group. J Hepatol 2004:41:677-83.

[30] Bottazzo GF, Florin-Christensen A, Fairfax A, Swana G, Doniach D, GroeschelStewart U. Classification of smooth muscle autoantibodies detected by immunofluorescence. J Clin Pathol 1976;29:403-10.

[31] Cançado ELR, Vilas-Boas LS, Abrantes-Lemos CP, Novo NF, Porta G, Da Silva LC, et al. Heat serum inactivation as a mandatory procedure for antiactin antibody detection in cell culture. Hepatology 1996;23:1098-104.

[32] Alvarez F, Bernard O, Homberg JC, Kreibich G. Anti-liver-kidney microsome antibody recognizes a 50,000 molecular weight protein of the endoplasmic reticulum. J Exp Med 1985;161:1231-6.

[33] Codoñer-Franch P, Bernard O, Maggiore G, Alagille D, Alvarez F. Clinical and immunological heterogeneity of anti-liver-kidney microsome antibody-positive autoimmune hepatitis in children. J Pediatr Gastroenterol Nutr 1989;9: 436- 40 .

[34] Abuaf N, Johanet C, Chretien P, Martini E, Soulier E, Laperche S, et al. Characterization of the liver cytosol antigen type 1 reacting with autoantibodies in chronic active hepatitis. Hepatology 1992;16:892-8.

[35] Beaufay H, Jacques P, Baudhuin P, Sellinger OZ, Berthet J, De Duve C. Tissue fractionation studies. 18. Resolution of mitochondrial fractions from rat liver into three distinct populations of cytoplasmic particles by means of density equilibration in various gradients. Biochem J 1964;92:184-205.

[36] Laemmli UK. Cleavage of structural proteins during the assembly of the head of bacteriophage T4. Nature 1970;227:680-5

[37] Towbin H, Staehelin T, Gordon J. Electrophoretic transfer of proteins from polyacrylamide gels to nitrocellulose sheets: procedure and some applications. Proc Natl Acad Sci U S A 1979;76:4350-4.

[38] Wasserman J, Glas U, Blomgren H. Autoantibodies in patients with carcinoma of the breast. Correlation with prognosis. Clin Exp Immunol 1975;19:417-22. 
[39] Mcmillan SA, Haire M. Smooth muscle antibody in patients with warts. Clin Exp Immunol 1975;21:339-44.

[40] Forslid J, Heigl Z, Jonsson J, Scheynius A. The prevalence of antinuclear antibodies in healthy young persons and adults, comparing rat liver tissue sections with HEp-2 cells as antigen substrate. Clin Exp Rheumatol 1994;12:137-41.

[41] Tan EM, Feltkamp TE, Smolen JS, Butcher B, Dawkins R, Fritzler MJ, et al. Range of antinuclear antibodies in "healthy" individuals. Arthritis Rheum 1997;40: 1601-11.

[42] Fernandez SA, Lobo AZ, Oliveira ZN, Fukumori LM, Prigo AM, Rivitti EA. Prevalence of antinuclear autoantibodies in the serum of normal blood donors. Rev Hosp Clin Fac Med Sao Paulo 2003;58:315-19.

[43] Watanabe A, Kodera M, Sugiura K, Usuda T, Tan EM, Takasaki Y, et al. AntiDFS70 antibodies in 597 healthy hospital workers. Arth Rheum 2004;50:892900.

[44] Fritzler MJ, Pauls JD, Kinsella TD, Bowen TJ. Antinuclear, anticytoplasmic, and anti-Sjogren's syndrome antigen A (SS-A/Ro) antibodies in female blood donors. Clin Immunol Immunopathol 1985;36:120 - 8.

[45] de Vlam K, De Keyser F, Verbruggen G, Vandenbossche M, Vanneuville B, D'Haese D, et al. Detection and identification of antinuclear autoantibodies in the serum of normal blood donors. Clin Exp Rheu 1993;11:393-7.
[46] Leser PG, Dellavance A, Barbosa SH, Guis G, Rodrigues SH, Sato EI, et al Distinctive features of antinuclear antibodies observed in health and in subjects with autoimmune rheumatic diseases. In: Conrad K, et al. From animal models to human genetics: research on the induction and pathogenicity of autoantibodies. Dresden, Pabst Science Publishers, 2004; p. 493-510.

[47] Lora PS, Laurino CCFC, Freitas AE, Brenol JCTB, Montecielo O, Xavier RM. Antinuclear antibodies (ANA) immunofluorescent patterns in HEp-2 cells on samples positive for Anti-SSA/Ro. Rev Bras Reumatol 2007;47:4-9.

[48] Dellavance A, Leser PG, Andrade LEC. Critical analysis of the antinuclear antibody test as tool in clinical practice. Rev Bras Reumatol 2007;47:265-75

[49] Hilário MO, Len CA, Roja SC, Terreri MT, Almeida G, Andrade LE. Frequency of antinuclear antibodies in healthy children and adolescents. Clin Pediatr (Phila) 2004;43:637-42.

[50] Lunel F, Abuaf N, Frangeul L, Grippon P, Perrin M, Le Coz Y, et al. Liver/kidney microsome antibody type 1 and hepatitis $C$ virus infection. Hepatology 1992; 16:630-6

[51] Mattalia A, Quaranta S, Leung PS, Bauducci M, Van de Water J, Calvo PL, Danielle $\mathrm{F}$, et al. Characterization of antimitochondrial antibodies in health adults. Hepatology 1998;27:656-61. 